\title{
Letters-to-the-Editor From 25 Years Ago
}

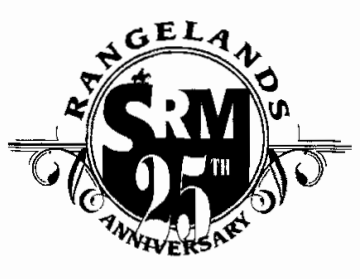

Editor's Note-The following two letters-to-the-Editor were published in the August 1979 issue. The author of the first letter, Dave Fischbach, was SRM President in 1993. The second author, Don Cox, was SRM president in 1969. Have the concerns changed?

\section{Speak Out Space:}

How rapidly flow the waters of time. Seems like only the other day we were packing our bags to head for Casper, and now that is far behind us and green grass is here along with calving and lambing. I think it is time to pull our heads out of the water for a few minutes and examine where we have been lately and where we might be headed in the future.

Cattle numbers in this country as well as many foreign countries are considerably lower than they have been in a long time. Prices of beef and live cattle are at an all time high. Many of us are actually again beginning to feel somewhat optimistic about this multi-billion dollar gambling game we call the cattle business. We may even have to pay some substantial income tax this year if we can keep our anti-friends at that epitome of paperwork on the banks of the Potomac from slipping an unneeded and unwanted mouse into our lunchbox in the form of price controls. Some officials are now recommending one beefless day a week to the consuming public. In addition to this, the federal government is cutting back on its purchases of beef for the armed forces, school lunch programs, etc.

Throughout the spring months, we have seen yearling heifers selling for steer price or more. These heifers will soon be a part of the nation's cow herd and supply will again reach a point where we have a surplus. If the government just leaves us alone, we producers will again slit our own throats by over-supplying the country with beef and the consumer will again be able to eat 1 steak for less than "peanuts."

Not too many years ago, the price of a barrel of crude oil was about the same as a bushel of wheat. Resuming this trading a bushel of wheat for a barrel of crude oil to the OPEC nations might be something to consider. They can either pay more for wheat, charge less for oil, or drink crude oil. Maybe when beef is again in a surplus situation, as it will be within 3 years, we could work some beef into this trade too.

For the past 30 years or so, our ranch here in western South Dakota has been involved in the practice of spaying all the heifers we don't keep for our own replacements. I certainly would recommend to the producers who read this publication that they consider it. It is the only sure way I know of to keep down cow numbers in this country. In an article currently under preparation for publication in Rangelands, I will elaborate on this subject. By the way, I would like to see the title of the JRM changed to Journal of Range Science, and Rangelands changed to Range Management Journal or Journal of Range Management. How do you feel about it? Let your opinion be heard.

So much for this time. Where do we go from here?-David A. Fischbach, Faith, S. Dak.

Editor's (Danny Freeman) Note: Dave is a rancher and past president of the South Dakota Section, SRM.

Some demographers are predicting the world's human population will reach 7 billion by the year 2000 . Should this be the case, food production will need to nearly double in this same time frame. Two years ago a world Food Conference was held in Rome supposedly to deal with impending food shortages. Most of the dialogue revolved around emergency food distribution (in the main from the U.S.) to starving people. They failed to address the fundamental issue, the production of food where it is needed. Apparently they didn't solve the distribution problem either. Current news indicates half of the world's people still go to bed hungry and some people are starving in Africa. 
What will the situation be 25 years from now? Here in the U.S. we are experiencing temporary shortages of production materials now. Also, in the past the better job agriculture did producing food the poorer it was paid. This is cited as one of the major problems limiting food production in the developing countries. If the increases in food production are made near the area of need, it would make the distribution problem smaller. Mismanagement of the soil will need to be controlled. Only about $7 \%$ of the world's land surface is classified suitable for intensive cultivation. In the U.S. alone some 3 million acres a year are being lost to urban sprawl, highways, and other non-food producing uses. They aren't making any more land but we are sure using a lot of productive acres up.

There are other problems! Some of us have been promoting Range Management and Performance Testing for over 25 years with little response from the industry as a whole. It took about that long for hybrid corn to become established as a common practice. Benefits could be demonstrated in one crop year. Both Range Management and Performance Testing are long-range practices. Gains, however, can be permanent and are energy efficient. The increases in crop production in the U.S. in the last decade haven't been energy efficient. This factor will become more and more important.

An adequate supply and equitable distribution of food is a problem we must come to grips with earnestly and soon. History teaches us that most squabbles between nations have been over land to grow food or to obtain other natural resources. Time is getting short.-Don Cox, Mullen, Nebr.

Editor's (Danny Freeman) Note: Don is a rancher and past president of the Society. This treatise by him has been published in two Section NewslettersSouth Dakota and Nebraska. It has a message I thought all readers of Rangelands would be interested in.

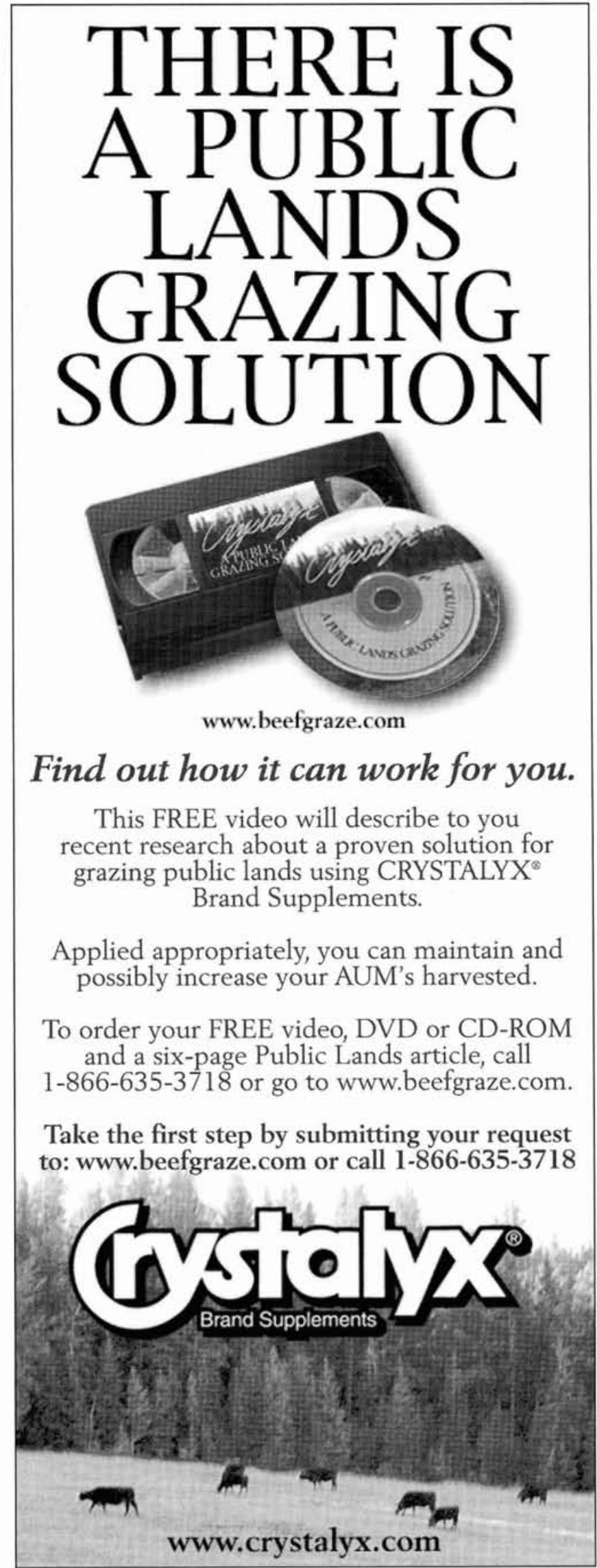




\section{Resource Roundup}

\section{Technology Breakthroughs}

What technologies changed agriculture most in the past 10 years? New Mexico State University ag economist and futurist Lowell Catlett says five simple but profound technologies came to be important over the last decade.

Catlett says the first was the release and improvement of GPS (Global Positioning Systems), which is leading to a whole new wave of accuracy in precision farming tools.

Biotechnology and the growth of the Internet place second and third respectively on Catlett's list of most influential technology.

Fourth was the improvement in weather satellite accuracy. "Surprising, I think this has probably done as much for agriculture in the last decade as anything," Catlett says. "We've started getting a new level of forecasting, especially on potential freeze dates and simply higher levels of forecasting accuracy."

Number five was the cell phone. "It may seem small and insignificant, but it is truly saving us precious time.

What technological advances can we expect to see by 2013? Futurist Mike Boehlje at Purdue's Center for Food and Agriculture Business predicts three types of technology to gain in popularity:

1) Technology to manipulate growth processes of plants and animals. Essentially, he sees a continuation of biotech work that has already developed such crops as Bt corn and Roundup Ready soybeans.

2) Technology for monitoring and measuring systems. Expect more use of GPS and remote sensing, and

3) Automated process control technology that will include high-tech sensors that monitor grass and grain crop's water and fertility levels, humidity amounts, etc. for site specific management practices.

Courtesy of Farm Industry News Magazine, February 2003

\section{Keep Water Quality In Mind}

Poor water quality can reduce livestock health and performance, according to South Dakota State University research.

Extension beef specialist Trey Patterson says calves on high quality water tend to drink more, eat more and gain more than calves on poorer quality water. In contrast, he says, "We know that cattle can die if we give them really poor quality water to drink."

Patterson is among a team of animal and range scientists and Extension educators conducting studies in western South Dakota to learn more about the impact water quality has on livestock performance.

The data they've collected thus far suggests pastured steers on good quality water (water with 1,000 ppm total dissolved solids (TDS) or less) gain at least $0.2 \mathrm{lb}$./day more than those on the poorer water (water with more than 7,000 ppm TDS.) "That works out to about 1.85 pounds per head average daily gain compared to 1.66 pounds for those on poorer water.

In feedlots, Patterson's reseach has shown poor water quality can reduce daily gains of steers on a growing ration by $0.4 \mathrm{lb}$./day and increase the incidence of sickness and death loss. In the South Dakota study, the group of steers on the poorest quality water had a $14 \%$ sickness rate and $5 \%$ death loss during the summer of 2001.

To combat the effects of poor quality water, Patterson recommends testing all water sources on your ranch or feedlot in at least two different years to get an idea of water quality on your operation. Stock dams and dugouts should be tested at least once in the spring, and again in late summer or fall if you plan to utilize the water source at that time.

Patterson stresses that there is no way to determine whether water is high in sulfates or total dissolved solids simply by looking at it. "The only way to determine quality is to have a sample analyzed," he says.

If water sources on your operation turn out to be sub-par in quality, Patterson says there are management solutions that may help make them useable.

"Water quality should be considered as part of 
your annual grazing plan, and if some water sources are poorer quality you need to devise a plan to work that into your grazing system," Patterson says.

For example, he recommends utilizing stock dams with marginal water quality early in the grazing season before evaporation during summer increases salt concentrations in the water.

He also points out that young cows often have higher nutritional requirements and can have more health problems with sub-par water. Therefore, plan to utilize dry cows or low producing cattle in pastures with marginal water supplies. Weaning calves early can also reduce the water quality needs of lactating cows and make them more able to utilize lower quality water.

Patterson says blending marginal water with higher quality water may also be a way to keep costs minimal while still providing livestock a better source of water.

Lastly, producers can consider developing water pipelines to pastures. Although this is an expensive alternative, if water quality is taking its toll on ani- mal performance, it may be an economical option. And, there are cost-share programs available from the Natural Resources Conservation Service to help develop water supplies for livestock.

\section{A Case For Saving Farm \& Ranch Land}

A recent American Farmland Trust survey shows that privately owned farm, ranch and forest lands boost community coffers by contributing more in tax revenues than they require back in public service. In contrast, residential development requires costly public services that surpass its tax contributions.

The report, Cost of Community Services Studies; Making the Case for Land Conservation costs $\$ 16.95$ To order, visit www.farmland.org or call 800-370-4879.

Resource Roundup is compiled by Kindra Gordon. Contributionswelcome at kindras@gordonresources.com or call (605)722-7699. 